\title{
Experimental Analysis of Single Glazing, Double Glazing and Triple Pass Solar Dryer
}

\author{
Dr. Vijay R Khawale, Assistant Professor, DBACER Nagpur, India, vijay.khawale46@gmail.com
}

Vilas G Dhore, Assistant Professor, KJSCE, Mumbai, India, vilasdhore@gmail.com

\begin{abstract}
Adjustable Multi glazing solar drying system is designed and fabricated for experimental study. The arrangement is made in the present model such that it can be wok as a single glazing, double glazing and multi-glazing solar dryer by adjusting the plain window glass (Glazing). The performance analysis and comparison of Single glazing (SGSD), double glazing (DGSD) and Triple pass solar drying system (TPSD) have been conducted by using red chilli. The performance curves show the effect of solar intensity on the collector efficiency, drying efficiency and pick-up efficiency of solar drying system. The collector efficiency of TPSD increased by $28.8 \%$ and $53 \%$ as compared to DGSD \& SGSD respectively at average value of solar radiation $674.4 \mathrm{~W} / \mathrm{m}^{2}$ at $26.90 \mathrm{gm}$ per second of air mass. The initial moisture content in red chili was measured and found 78.8 (wb) reduced to minimum moisture content $9.8 \%$ (wb).It could be concluded that, the time required to dry the red chilli in TPSD is minimum as compared to SGSD and DGSD.
\end{abstract}

Keywords - Single Glazing, Double Glazing, Triple pass, solar dryer, Red chilli

\section{INTRODUCTION}

From old age the solar energy used for drying agriculture product. Solar energy is used as a source of energy in solar dryer which is nonrenewable resource. In India solar energy is easily available excepting some limitations for crop drying in rural areas. Many researchers have been developed a solar dryer by using different types of solar air collector. Solar air collector works as a heat exchanger where solar heat energy transfer to air. Thus the hot air obtained from solar collector is used in various applications like space heating [1,2], green house heating[5], product heating $[3,4]$ and air conditioning system[6,7 Applications like drying and space heating, the temperature of air require low below $65^{\circ} \mathrm{C}$ which is easily possible in solar air collector (heater). Forson et al [8] has been developed a single glass glazing and double Glass glazing used solar air collector. Many researchers have been presents solar dryers by using different types of solar air collectors All these designed solar dryers was examined for their performance such as heat absorbed by air in collector and drying process[9-11 A solar crop dryer has designed and the performance of single pass SAC [12] and double pass SAC [13-15] were analyzed experimentally. Sencan and Ozdemir [16] was noted that the thermal efficiency of solar collector is depends on types of material, size of various parts and layout. S.Wijeysundera et al. [17] was compared the DPSAC and SPSAC and observed that the DPSAC was better by increasing of $10-15 \%$ of collector efficiency than SPSAC. Aldabbagh et al. [18]. was found in his experimentation that the maximum efficiency of SPSAC and DPSAC was $46 \%$ and $84 \%$ respectively means that 35 to 46 percent greater than SPSAC. Sopian et al. [19] studied in experimentation that the collector efficiency was about $59 \%$ to $69 \%$ of DPSAC including porous absorber plate. A Solar collector which includes with porous absorber plate and double air passage has a higher thermal efficiency about $75 \%$ more than thermal efficiency of conventional solar air collector at normal operating condition. Jain and Jain [20] has been noted from experimentation that the dimension of solar air collector are significantly affects on the temperature rise of air. Jain [21] has presented multi tray crop dryer for drying of paddy crop. The performance of multi pass solar air heater was satisfactory.

Thus there is need of development in solar air collector which is a major component of solar dryer. The heat gained by air is used to vaporize moisture content in agriculture product per unit time on which drying time is dependant. In this study a solar dryer with multi pass solar air collector was developed and Multi-pass Solar crop dryer was designed and performance was tested for chilli drying

\section{Material And Methods}

\section{Solar air collector $(\mathrm{SAC})$ :}

Solar air collector is a major part of solar drying system. In this study three types of flat plate collectors are used. The size of SAC is $1 \mathrm{~m} \mathrm{x} 2 \mathrm{~m}$. Two flat plate of $0.9 \mathrm{~mm}$ thick which is made up of aluminium sheet material with black painted has used as an absorber plate. First absorber plate has fixed in such a way that, it faced towards south and inclined with 30 degree to horizontal frame of SAC has made up of thick wooden material. A white transparent glass of $4 \mathrm{~mm}$ has been used as a glazing to reduce 
convection losses. The arrangement is made in the present model such that it can be wok as a single glazing. Double glazing and Triple-pass solar dryer by adjusting the plain window glass (Glazing).

\section{Drying cabinet (DC)}

The drying cabinet has made up of thick wooden material in $1 \mathrm{~m} \times 1 \mathrm{~m} \times 1 \mathrm{~m}$ size. Exhaust Exhaust fan with a capacity of $100 \mathrm{gm}$ air mass flow per second has installed on the top of dryer cabinet. Air fan was used to maintain a mass flow rate during the drying process. Uniform evaporation of moisture and negative pressure in collector was created due to the flow of air causing the uniform heating of air in the collector and reduced the convection heat loss. Drying cabinet consisting of 2 trays having $90 \%$ perforation are capable of holding $10 \mathrm{Kg}$ (Each tray $5 \mathrm{Kg}$ ) chilli per batch. A gap of $50 \mathrm{~mm}$ was provided in two trays for circulation of air.

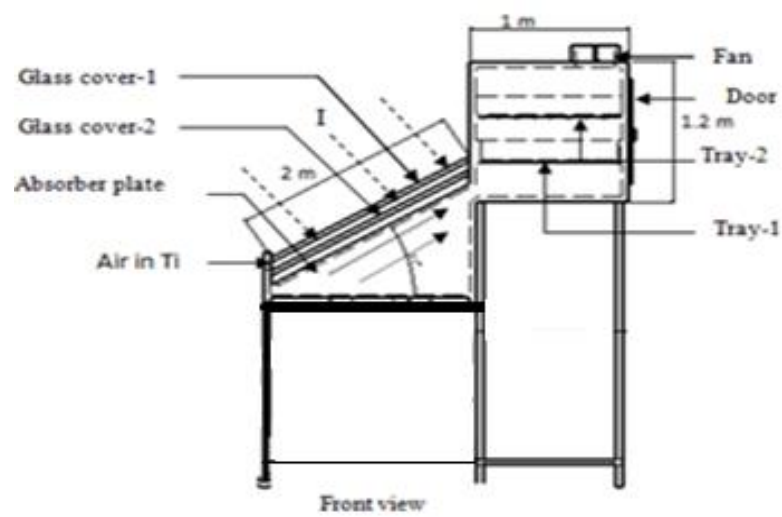

Figure1. Schematic diagram of adjustable solar drying system

\section{Experimental Methods:}

Figure 1 shows the experimental set up which has used to study the effect of single glazing, double glazing and Triplepass solar drying system on the efficiencies and drying rate at different solar intensity, relative humidity and ambient temperature.

\section{Measurement of moisture content in Crop (MCC)}

The quantity of MCC can be measured on wet basis, dry basis or percentage basis. Electric oven has used to dry the crop at constant temperature $105 \pm 1{ }^{\circ} \mathrm{C}$. The electronic weighing scale has used to measure the weight of crop. The initial moisture content in crop (Mi) and final moisture content in crop (Mf) were measured by using weighing scale.

Following equation was used to find the moisture content on wet basis. Till the end of complete drying, this method has been repeated at the interval of 1 hour.

$\mathrm{M}_{\mathrm{wb}}=\frac{\left(\mathrm{M}_{\mathrm{i}}-\mathrm{M}_{\mathrm{d}}\right)}{\mathrm{M}_{\mathrm{i}}} \times 100$

\section{Determination of dryer thermal efficiency}

Thermal efficiency of dryer was calculated by using following formulae
$\mathrm{I}_{\mathrm{d}}=\frac{\mathrm{M}_{\mathrm{w}} \mathrm{h}_{\mathrm{fg}_{\mathrm{g}}}}{\mathrm{m}_{\mathrm{a}} \mathrm{C}_{\mathrm{pa}}\left(\mathrm{T}_{\mathrm{d}}-\mathrm{T}_{\mathrm{i}}\right)}$

\section{Determination of Pick-up efficiency}

Pick-up efficiency of dryer was calculated by using following formulae

$\mathrm{I}_{\mathrm{p}}=\frac{\mathrm{M}_{\mathrm{w}} \mathrm{Mw}}{\mathrm{m}_{\mathrm{a}} \Delta \mathrm{t}\left(\mathrm{w}_{\mathrm{ce}}-\mathrm{w}_{\mathrm{ci}}\right)}$

\section{Measurement of rate of drying (DR)}

Time required for drying has been proportional to the difference between initial moisture in crop and moisture content in crop after complete drying. DR also proportional to equilibrium moisture content [22].

Thin layer drying was assumed for a red chilli. Following equation (4) used to calculate the DR

$\mathrm{DR}=\frac{\mathrm{dM}}{\mathrm{dt}}=-\mathrm{k}\left(\mathrm{M}_{\mathrm{i}}-\mathrm{M}_{\mathrm{e}}\right)$

\section{Determination of collector efficiency}

$\mathrm{I}_{\mathrm{c}}=\frac{\mathrm{m}_{\mathrm{a}} \mathrm{C}_{\mathrm{pa}}\left(\mathrm{T}_{\mathrm{o}}-\mathrm{T}_{\mathrm{i}}\right)}{\left(\mathrm{I} \& \mathrm{~A}_{\mathrm{c}}\right)}$

\section{RESULT AND DISCUSSION}

A design and fabricated solar drying system has been used to dry the red chilli.

The tests were conducted during the sunshine hours in day time. Figure 2 shows the deviation in relative humidity and SAC outlet temperature of air and ambient temperature. The average SAC outlet air temperature means at the entry of dryer cabinet was about $51^{\circ} \mathrm{C}, 43^{\circ} \mathrm{C}$ and $39.2^{\circ} \mathrm{C}$ for TPSD, DGSD and SGSD respectively. The SAC outlet air temperature (Average) equal to the temperature at the entry of dryer cabinet was about $51^{\circ} \mathrm{C}, 43^{\circ} \mathrm{C}$ and $39.2^{\circ} \mathrm{C}$ for TPSD, DGSD and SGSD respectively.

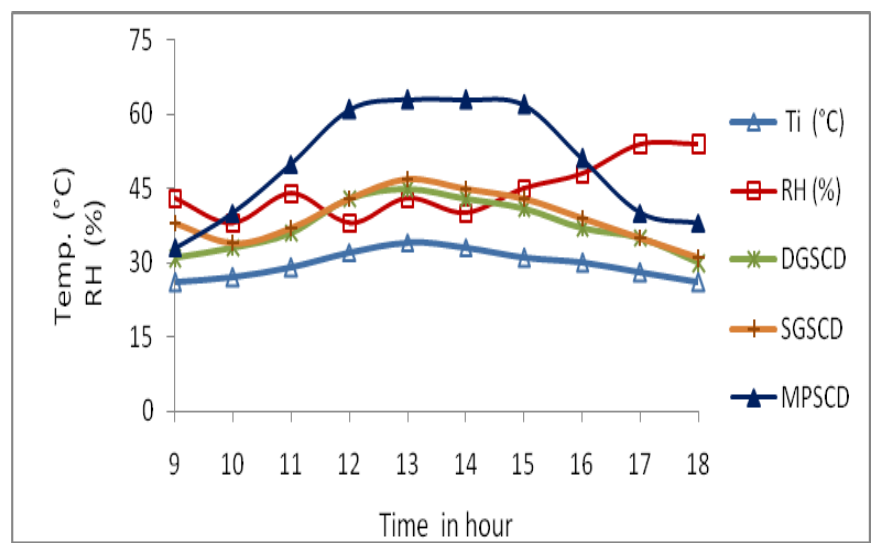

Figure 2. Variatn of Ti, To and RH during the sunshine day At the entry of dryer cabinet, the maximum air temperature was noted equal to $63^{\circ} \mathrm{C}$ during peak sunshine hours. Air temperature curves of different types of solar dryer system shows that it can be used to dry various types of agricultural product effectively. During the experimentation it has been 
noted that the maximum solar intensity equal to $910 \mathrm{~W} / \mathrm{m}^{2}$ and average DBT and WBT were $32^{\circ} \mathrm{C}$ and $25.9^{\circ} \mathrm{C}$ respectively. In a drying cabinet, initially the air has a relative humidity of about $33 \%$ and rise gradually during the drying process up to $70 \%$.

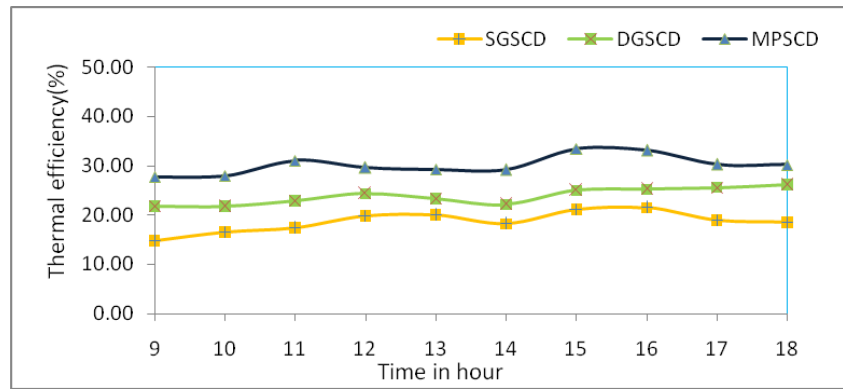

Figure 3. Comparison of SAC thermal efficiency of SGSD, DGSD and TPSD

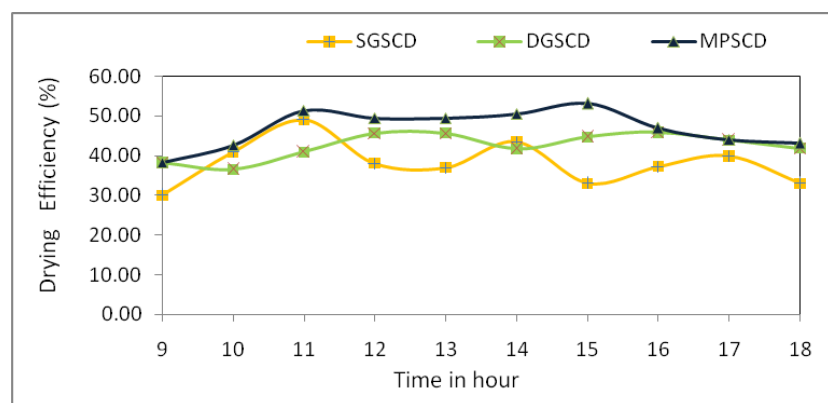

Figure 6. Drying rate of red chili vs a moisture content during drying in SGSD (db)

From the curves shown in graph it has observed that the drying rate of chilli was decreased as the moisture content has been decreased. At the beginning of drying process, drying rate has been high due to higher moisture content in chili. Initially moisture evaporated from outer and then inner surface of chilli. As the drying process go on, the moisture has removed from surface of chilli and then evaporation started from inner surface. As the moisture removal has started from inner of chilli causing an evaporation rate has been decreased. Hence the drying rate was depends on the drying time and moisture content in the materials.

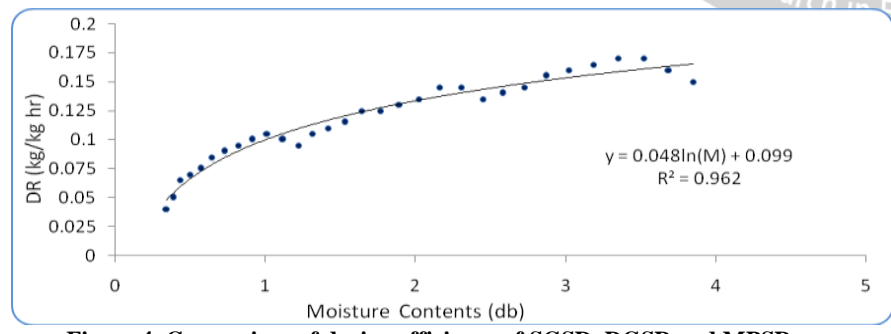

Figure 4. Comparison of drying efficiency of SGSD, DGSD and MPSD

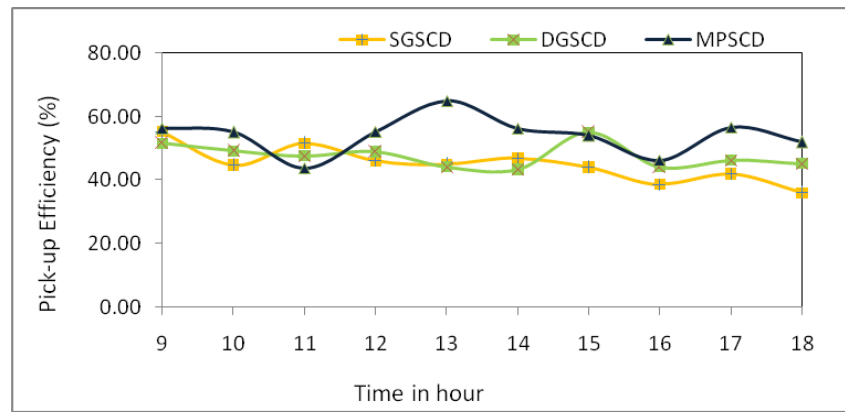

Figure 5. Comparison of pick-up efficiency of SGSCD, DGSCD and MPSCD

From the Figure 3 to Figure 5 , At Iavg $=675 \mathrm{~W} / \mathrm{m}^{2}$, $\mathrm{Tamb}=33^{\circ} \mathrm{C}$ and $\mathrm{ma}=26.90 \mathrm{gm} / \mathrm{s}$, the $\mathrm{SAC}$ thermal efficiency has been noted equal to $29.80 \%, 24.70 \%$ and $19.0 \%$ for TPSD, DGSD and SGSD respectively. From graphical presentation it has been noted that the TPDC is more efficient than DGSD and SGSD.

From the graphical analysis, it has been noted that the average drying efficiency equal to $46.35 \%, 38.3 \%$ and $37.1 \%$ for TPSD, DGSD AND SGSD respectively. Similarly pick up efficiency has been noted equal to 55.045, $50.05 \%$ and $45 \%$ for the TPSD, DGSD and SGSD respectively. As this results has been reliable with literature available, the heat absorbed by air is considerable and reduces the conventional heat losses in TPSD [20, 21].

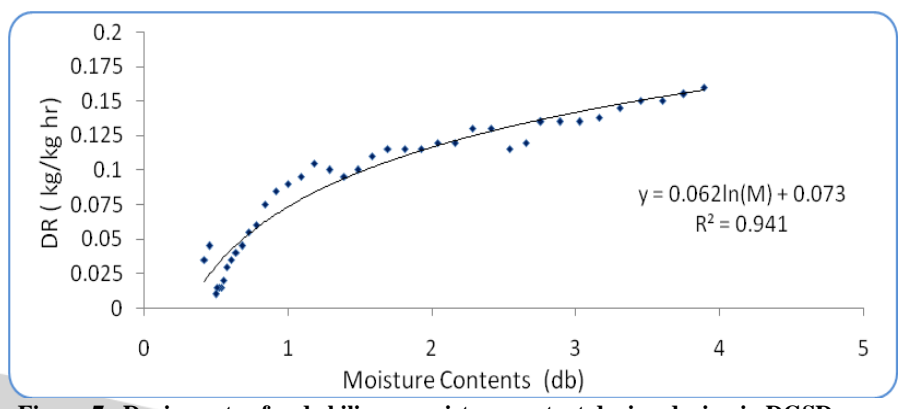

Figure 7. Drying rate of red chili vs a moisture content during drying in DGSD (db)

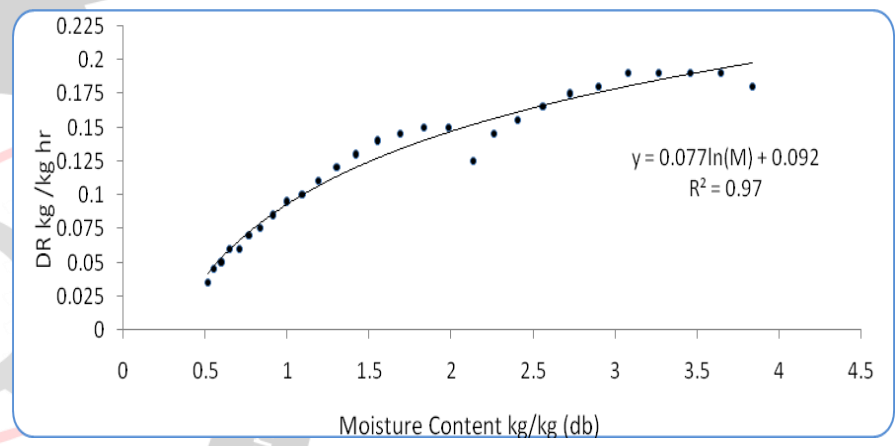

Figure 8. Drying rate of red chili vs a moisture content during drying in TPSD (db)

From graph the following regression equation can be writing for drying rate of chilli.

For SGSD, Drying rate of chilli:

$\mathrm{DR}=0.062 \ln (\mathrm{M})+0.073 \quad\left(\mathrm{R}^{2}=0.941\right)$

For DGSD, drying rate of chilli:

$\mathrm{DR}=0.048 \ln (\mathrm{M})+0.099 \quad\left(\mathrm{R}^{2}=0.96\right)$

For TPSD, drying rate of chilli:

$\mathrm{DR}=0.077 \ln (\mathrm{M})+0.092 \quad\left(\mathrm{R}^{2}=0.97\right)$

It is also evidence from the equations 6,7 and 8 for red chillies, drying rates were observed higher in TPSD than DGSD and SGSD.

\section{CONCLUSIONS}

The performance analysis has been done by experimentation on red chilli using three types of solar drying system.

As compare to SGSD \& DGSD, the temperature of air at inlet of dryer cabinet was more. From that it was ensured that the heat transfer rate has increased causing an increased in the collector efficiency. The thermal efficiency of SAH 
of TPSD was found in the range of $27.61 \%$ to $39.9 \%$ at steady mass flow rate. Also found the drying and pick up efficiency of TPSD was better compared to other solar drying system. The performance of TPSD is comparable with the many studies in literature.

The chilli was used to determine the performance of newly designed solar dryer in experimentation. The high temperature can be maintained inside the TPSD. Due to temperature rise reduced the drying time than double glass and single glass solar crop dryer. At the beginning of experimentation the red chilli was wet with moisture content measured up to $78.8 \%$ (wb). Finally the moisture reduced up to $9.8 \%$ (wb) which is help to store the chilli for long period. From the regression equation it is concluded that the drying time for red chilli is less in TPSD and suitable to maintain quality.

\section{NOMENCLATURE}

SGSD Single glazing solar dryer

DGSD Double glazing solar dryer

TPSD Triple pass solar dryer

DR Drying rate

RH Relative humidity

$T_{O} \quad$ Final air temperature in Collector

$T_{i} \quad$ Initial air temperature in collector

$m_{a} \quad$ Mass flow rate of air in dryer cabinet

$C_{p a} \quad$ Specific heat of air

$T_{d} \quad$ Drier (plenum) air temperature

$h_{f g} \quad$ Latent heat of water

$M_{w} \quad$ Mass of moisture evaporated in time $\Delta t$

$W_{c e} \quad$ Exit air absolute humidity

$w_{c i} \quad$ Inlet (plenum) air absolute humidity

I Hourly effective solar radiation on absorber plate

$I_{\text {avg }} \quad$ Average solar radiation on absorber plate

$A_{c} \quad$ Area of absorber plate
[9] Turgut O, Onur N. "Design and performance of a special solar collector and its application to drying of agricultural products," Gazi University J Sci 2000; 13(3):639-48.

[10] Koyuncu T. "Performance of various design of solar air heaters for crop drying applications, " Renew Energy 2006;31:1073-88.

[11] Momin AME, Saini JS, Solanki SC. "Heat transfer and friction in solar air heater duct with V-shaped rib roughness on absorber plate," Int J Heat Mass Transfer 2002; 45(16):3383-96.

[12] Bulut H, Durmaz F. "Designing, manufacturing and experimental analysis of solar air collector," I. National solar and hydrogen energy conference, UGHEK'2006, Eskis_ehir, Turkey; 21-23 June 2006. (in Turkish).

[13] Fudholi A, Sopian K, Ruslan MH, Alghoul MA, Sulaiman MY, Othman MY, et al. "Thermal efficiency of double pass solar collector with longitudinal fins absorbers," Am J Appl Sci 2011; 8(3):254-60.

[14] Ramani BM, Gupta A, Kumar R. "Performance of a double pass solar aircollector," Sol Energy 2010; 84:1929-37.

[15] Ho CD, Yeh HM, Chen TC. "Collector efficiency of upward-type double pass air heaters with fins attached," Int Commun Heat Mass Transfer 2011; 38:49-56.

[16]Sencan A, Ozdemir G. "Comparison of thermal performance predicted and experimental of solar air collector," J Appl Sci 2007; 7(23):3721- 8 .

[17] Wijeysundera NE, Ah LL, Tjioe LE. "Thermal performance study of two-pass solar air heaters," Sol Energy 1982; 28(5):363-70.

[18] Aldabbagh LBY, Egeliog lu F, _Ilkan M. "Single and double pass solar air heaters with wire mesh as packing bed," Energy 2010; 35:3783-7.

[19] Sopian K, Alghoul MA, Alfegi EM, Sulaiman MY, Musa EA. "Evaluation of thermal efficiency of double-pass solar collector with porous-nonporous media," Renew Energy 2009; 34:640-5.

[20] Jain D, Jain R K. "Performance evaluation of an inclined multi-pass solar air heater with in-built thermal storage on deep-bed drying application," J Food Eng 2004; 65:497-509.

[21] Jain D. "Modeling the system performance of multi-tray crop drying using an inclined multi-pass solar air heater with in-built thermal storage," J Food Eng 2005; 71: 44-54.

[22] Butler JL, Troeger JM. "Drying peanuts using solar energy stored in a rockbed, Agricultural energy," vol. I, solar energy, selected papers and abstracts, ASAE Publication, St Joseph, Michigan; 1980

\section{REFERENCES}

[1] RET Screen. Chapter; "solar air heating project analysis, clean energy project analysis," textbook, catalogue no: M39-100/2003E-pdf. International Clean Energy Decision Support Centre, Canada; 2004.

[2] Christensen C. Federal energy management program: transpired collectors (solar preheaters for outdoor ventilation air); 1998.

[3] Karim MA, Hawlader MNA. "Development of solar air collectors for drying applications," Energy Convers Manage 2004;45:329-44.

[4] Fudholi A, Sopian K, Ruslan MH, Alghoul MA, Sulaiman MY. "Review of solar dryers for agricultural and marine products," Renew Sust Energy Rev 2010; 14(1):1-30.

[5] Benli H, Durmus_ A. "Performance analysis of a latent heat storage system with phase change material for new designed solar collectors in greenhouse heating, ” Sol Energy 2009; 83:2109-19.

[6] Sokhansanj S, Schoenau GJ. "Evaluation of a solar collector system with thermal storage for preheating ventilation air in farm buildings," Energy Convers Manage 1991; 32(2):183-9.

[7] Cordeau S. "The performance of a solar air pre-heater system for the ventilation of two commercial poultry barns," Master Thesis, Department of Bioresource Engineering McGill University, Montreal, Canada; 2010.

[8] Forson FK, Nazha MAA, Rajakaruna H. "Experimental and simulation studies on a single pass, double duct solar heater," Energy Conver Manage 2003; 44:1209-27. 